\title{
PRAMOEDYA ANANTA TOER'S NOVELS ON INDEPENDENCE REVOLUTION FROM THE PERSPECTIVE OF JOURNALISTIC HEGEMONY
}

\author{
(Novel Revolusi Kemerdekaan karya Pramoedya Ananta Toer \\ dalam Perspektif Hegemoni Jurnalistik)
}

Azman Ismail

azman@aswara.edu.my

Fakulti Penulisan Kreatif dan Filem, Akademi Seni Budaya dan Warisan Kebangsaan (ASWARA).

To cite this article (Rujukan artikel ini): Azman Ismail. (2021). Pramoedya Ananta Toer's novels on independence revolution from the perspective of journalistic hegemony. Malay Literature, 34(1), 69-88. http://doi. org. 10.37052/ml34(1)no4

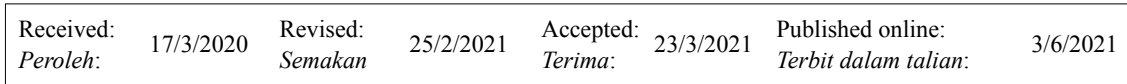

\begin{abstract}
The journalistic hegemony conceptual framework is an approach in the study of literary works in all genres. This framework functions on the principle that a literary work is a creative medium that comprises facts, data and reality that is fictionalized for the purpose of spreading information to its readers, similar to that of conventional media. Based on documentary research and content analysis, this study proves that Pramoedya Ananta Toer's novels on the theme of the Indonesian National Revolution (1945-1949)—Di Tepi Kali Bekasi (1951), Keluarga Gerilya (1955), Sekali Peristiwa di Banten Selatan (1963) and Larasati (2003) are creative media intended to raise awareness among the Javanese marginal class. The focus of this study is to prove that Pramoedya Ananta Toer's novels are creative media designed to create hegemony and mental awareness, both intellectually and ideologically, in the social class he represents. The journalistic hegemony conceptual framework is based on the principle of comparative hegemony by Antonio Gramsci and the communication theory. The Hypodermic Needle Theory places these novels on revolution by Pramoedya Ananta Toer as having the
\end{abstract}

(C) Dewan Bahasa dan Pustaka. 2021. This work is licensed under the term of the Creative Commons Attribution (CC BY) (http://creative commons.org/licenses/by/4.0/)

ISSN: 0128-1186 e-ISSN: 2682-8030 
function of spreading information creatively in order to raise awareness and subsequently free the marginal class of false consciousness nurtured by the traditional bureaucratic elites and Dutch colonizers in Java.

Keywords: Journalistic hegemony, intellectuality, ideology, Hypodermic Needle Theory, marginal class

\begin{abstract}
Abstrak
Kerangka konseptual hegemoni jurnalistikmerupakan pendekatan dalam kajian terhadap kedudukan karya sastera dalam semua genre. Kerangka ini berfungsi atas prinsip bahawa sesebuah karya sastera merupakan media kreatif yang memiliki fakta, data dan realiti yang difiksyenkan yang bertujuan menyebarkan maklumat kepada pembacanya yang berperanan seperti media konvensional. Berdasarkan penyelidikan perpustakaan dan analisis kandungan, kajian ini membuktikan novel Pramoedya Ananta Toer yang bertema Revolusi Kemerdekaan Indonesia (1945-1949), iaitu Di Tepi Kali Bekasi (1951), Keluarga Gerilya (1955), Sekali Peristiwa di Banten Selatan (1963) dan Larasati (2003) merupakan media kreatif untuk mewujudkan kesedaran kelas marginal Jawa. Fokus kajian ini adalah untuk membuktikan bahawa novel Pramoedya Ananta Toer merupakan media kreatif untuk menggerakkan hegemoni dan kesedaran mental kelas sosial yang diwakilinya dalam aspek intelektual dan ideologi. Kerangka konseptual hegemoni jurnalistik yang dibina berdasarkan prinsip hegemoni tandingan oleh Antonio Gramsci dan teori komunikasi. Teori Jarum Hipodermik meletakkan novel revolusi Pramoedya Ananta Toer berfungsi menyampaikan informasi secara kreatif dengan tujuan mewujudkan kesedaran dan seterusnya membawa kelas marginal Jawa keluar daripada kesedaran palsu yang dibina oleh para elit birokrasi tradisional dan kolonialisme Belanda di Jawa.
\end{abstract}

Kata kunci: Hegemoni jurnalistik, intelektual, ideologi, Teori Jarum Hipodermik, kelas marginal

\title{
INTRODUCTION
}

Literary works in all genres - whether they are novels, short stories, poetry and drama - have a close relationship with the author's ideology and intellectual leanings. The literary genre is a reflection of the author's viewpoint, philosophy and perception through the creative media approach (representational media) to convey information to the readers (Fiske, 1993: 16-17; Misran, 2006: 7071). The narrative or plot structure in a literary work can be understood as 
fictionalized reality, facts and data built up by the author so that it functions similar to conventional media (newspaper, magazine and electronic media), which is to convey information to their readers. Generally, the creative process and creation of a literary work links the author to issues in the existing social system, apart from the aesthetic value that places works of literature as a reflection of society influenced by the history of its social development, social classes and economic system (Eagleton, 1996: 5). A literary work, therefore, is a reflection of the author's ideology and intellectual leanings as well as a dialectic relationship between the author and the social environment based on the history of a certain social class that gave rise to it (Langland, 1984: 21).

The content and form of a literary work is the image of the social phenomena, ideology, class interests and history of a society as represented by the author. When it comes to novels by Indonesian authors, for example, Pramoedya Ananta Toer (PAT) (1925-2006), who highlighted the theme of the Indonesian National Revolution (1945-1949) in Larasati (2003), Sekali Peristiwa di Banten Selatan (1963), Di Tepi Kali Bekasi (1951) and Keluarga Gerilya (1955), can be said to have founded the role of the novel as creative media. PAT used his novels to express the interests of the Javanese marginal class, which was the main element in the traditional feudal and Dutch colonial systems for 350 years. Based on this approach, PAT developed a counterhegemony structure and war of awareness. The concept of war of awareness is an approach adapted from that of war of position developed by the Italian Marxist, Antonio Gramsci (1891-1937), in the theory of hegemony.

The adaptation directly places novels and other literary works as a medium of journalistic hegemony, referring to an approach for understanding the evolution of a new ideology and intellectual leaning as well as the development of counter-hegemony and war of awareness based on the role of creative media (Azman, 2014: 71-73). In his novels, PAT developed a discourse, an awareness movement and counter-hegemony based on the view that the Javanese marginal class was shackled by native political elite hegemony and Dutch colonial dominance. The effect would be able to make a huge impact on socioeconomic stability, way of thinking, ideology and intellectual development. The marginal characters he developed became the medium for him to emphasize on the aspirations, way of thinking, ideology and intellectuality as a form of counter-hegemony and war of awareness against the bureaucratic elites.

In the concept of hegemony by Antonio Gramsci, the bureaucratic elites are known as the political society that exerts hegemony, while the ordinary people are known as civil society, which is the group that is hegemonized. 
The political society refers to the bureaucratic elites who determine the type of power to be wielded, the legal system to be used and the method of dominance over the powerless marginal group, all framed by the intellectual and moral values being offered. The elites manipulate the marginal class through soft oppression without the latter being aware of it. In fact, the latter accepts the oppression as something appropriate until a certain hegemony is formed (Gramsci, 1970: 48; Azman, 2014: 28).

The acceptance of hegemony developed by the political society can only be unravelled through a comprehensive ideological and intellectual awareness within the marginal class. Ideological and intellectual awareness is generally stirred up by an organic intellectual group comprising authors, thinkers, journalists and others. They are responsible for creating war of awareness to free the marginal class from hegemony. Therefore, the function of the organic intellectual group is to foster a new way of thinking, ideology and new intellectual movement as an awareness that is antithesis to the political society's hegemony (Kalokowski, 1978: 240; Joll, 1977: 91-93; Sasoon, 1980: 134-46; Azman \& A. Halim, 2015). Based on the perspective of journalistic hegemony, authors make use of their individual intellect to develop ideologies that are closely linked to the social class they represent. In other words, they function as journalists in conventional media that is wholly responsible for disseminating information, but with the intention of creating awareness among the marginal class to come out from the false consciousness imposed by the political society.

False consciousness is created by the powerful elites in order to strengthen their power over the marginal class. This situation refers to the phenomenon of class domination, which the marginal class is not aware of, through various social instruments such as the arts, songs, religious institutions and others. Finally, the marginal class accepts both the ideology and common sense of the dominant class in the form of mutual consent and moral leadership between the two social classes (Azman, 2014: 221).

The characters in a novel based on the conceptual journalistic hegemony are of an inferior rank or subaltern. The marginal class characters developed by the author are adapted based on Gramsci's thinking as a way of destroying the hegemony of the elites in power and, at the same time, to create a counterhegemony. Based on this conceptual framework, a literary work is linked to the system and value network of the society that forms the social background of the author (Azman \& A. Halim, 2015). The text that is produced directly refers to the relationship between the author and the social class he represents, which involves social status, ideology, economic situation and the target group 
that will be reading the produced text. In this context, the author functions as a communicator and organic thinker who is responsible for conveying the collective interests of the marginal class, especially in ideology and intellectual matters.

A literary work is also produced based on issues of morals, values and worldview, coalescing into the collective awareness of the marginal class. This is based on the assumption that a literary text is intrinsically linked with the process of social validity, culture, ethics, morals and levels of intellectuality in the society. Just as in conventional media, in journalistic hegemony, a reality or social factor outside the text regarding the marginal class is transformed into a piece of work, according to the importance and reason it is written based on social structures, such as the institution, typology, ideology and collective needs of its group.

\section{ANTONIO GRAMSCI'S HEGEMONY THEORY}

Gramsci, in Selections from the Prison Notebooks (1987), did not state categorically what the term "hegemony" entails, which thus led to various interpretations. Clark (1977: 2), for example, defines hegemony as an approach by the political elite and dominant class to control the media and the field of education in order to reinforce their power. Specifically, Clark describes hegemony as the approach used by the ruling class or political society to control institutions that can generate a leaning towards the interests and awareness of the marginal group. In this context, the marginal class refers to the biggest class in a civil society that comprises farmers, labourers and workers.

The general public in Gramsci's discourse is the key to understanding the rise of capitalism, while in Marx's discourse, it is understood as the structure or link of output that leads to class conflict (proletarian and bourgeois). Clark also puts forward the term "functional hegemony," which functions as a medium to gain recognition of the dominant class' power through education, social organization, high culture, popular culture and common sense. Gramsci explains that there is an approach used by the dominant class to gain recognition of their power by the marginal class, such as the educational curriculum, popular culture, ideology and media, which the hegemonized class is generally not aware of (Forgacs, 1989).

Gramsci's conception differs from orthodox Marxism, which is of the view that pressure, oppression as well as overall domination by the country and capitalist class are the most important elements in establishing power (Azman \& A. Halim, 2014). According to Gramsci, the dimension 
of the marginal class and its relationship with the political society is important in getting acceptance because the marginal class would still need a power system to stabilize the superstructure and infrastructure of their lives. Among other things, they require an educational system, media, infrastructure and physical facilities for their livelihood even though it would mean dependence on the political society. Gramsci believes that civil society is the superstructure that represents the active and positive factor in the historical development, the cultural relationship and the development of an ideology in that society, which leads to a political agreement between the two social classes (Femia, 1981: 127-128). The history of the marginal class is very important in order to understand the intellectual movement and ideology of that class since it also leads to understanding the history of the dominant class (the bureaucratic elites and feudal class). However, the marginal class does not have enough strength to build their own history due to the shackles of hegemony created by the hegemony of the dominant class.

Gramsci describes this situation as a functional hegemony concept being applied by the political society to "force" the marginal class and subaltern group to agree with their power policy via particular mediums without the marginal class being aware of it. To overcome functional hegemony, he suggests the creation of an ideological and intellectual movement called counter-hegemony to create a new hegemony by the marginal class. By establishing hegemony, a social class or dominant group basically does not force their ideology onto a marginal class. Instead, the preference is to work towards enhancing their worldview so that the social group they dominate accept, believe and emulate the ideas, way of thinking and lifestyle they practice.

Relatively, this recognition of class dominance in Gramsci's discourse does not involve the kind of revolution dictated by Marx and Engel in Communist Manifesto (1845) and German Ideology (1845). It differs in that the whole idea, culture, values, morals and politics in hegemony are absorbed willingly (Lukacs, 1971: 46-50). However, the agreement between the two social classes is not static and stable. In fact, it is often in collision as a result of the roles played by the intellectual group, specifically the organic group that represents the interests of the dominated class (Bocock, 1986: 26-29).

The dominance of the political society succeeds in changing the worldview of the marginal class in a social system known as hegemonic contra-intellectual, which will then create moral leadership as the final process in hegemony 
(Simon, 1987: 43-44). The instability directly creates a counter-hegemony by the marginal class and subaltern group described by Gramsci as war of position. War of position is a situation of a collision of perspective and worldview of the groups that finally lead to a hegemonic clash between the marginal and political societies since the intellectual organic group representing that class has raised awareness. This awareness is brought about by news reporting in newspapers, magazines and literary works.

\section{Journalistic Hegemony and Text Criticism}

The term "journalistic" generally refers to the activity of writing, editing and publication of articles or news to be read by the public through the mediums of newspaper, magazine and electronics. According to Gramsci, media is the medium for the political society to dominate and control the marginal class and reinforce their hegemony towards them. However, media also plays the role of creating a counter-hegemony by the marginal class through discourses on new ideology and intellectuality in order to destroy the prevailing hegemony through an organic intellectual group (Gramsci, 1971: 124-125; Ives, 2004: 311-314). Through the media, the marginal class intellectuals push forward the ideology and intellectuality that can be summarized as the common sense and ideas of the marginal class to create a new hegemony, as done by PAT in his four novels that carry the revolutionary war theme.

The journalistic hegemony conceptual framework is based on the adaptation of the principle of journalism contained in the Hypodermic Needle Theory. This theory assumes that a piece of news published in mass media has a one-step flow that will reach the mass audience as a result of reading it in the newspaper or a magazine. The society or readers are the patients who will recover after being "injected" with the information they want or need to know, especially psychologically. This theory also assumes that mass media is simple, quick and has a huge impact on a society of passive receivers of information delivered by the reporter, journalist or writer (Elvinaro Ardianto et al., 2007: 61-62). A piece of news or write-up has the role of influencing a person, even if it is a one-way communication.

This theory also assumes that the readers can comprehend all the information given out by the reporter or journalist, thus enabling a new way of thinking among themselves. The main premise is that readers are a passive group who accept all information written by the writer, reporter or journalist, which then facilitates interaction between the writer and the reader that evokes sentiments stirred by the language, diction and syntax so much 
so that it succeeds in influencing the reader psychologically (Azman, 2014: 209-210; Astrid S. Susanto, 1987: 1; Littlejohn, 1999: 17).

Generally, the basis of the journalistic hegemony approach is the emphasis on ideological and intellectual awareness, which could create a counterhegemony by the marginal class. This war of awareness is a result of reading a work of literature. A literary work, including the novel, has a function similar to newspapers and magazines, which is to disseminate information that is fictionalized through a particular narrative structure, though still being tied to the reality of its theme (Azman \& A. Halim, 2015). War of awareness in journalistic hegemony is considered as the height of ideological and intellectual awareness going towards counter-hegemony, as put forth by Gramsci in the theory of hegemony by the marginal class, as a result of reading the media.

In his novels revolving around the Indonesian National Revolution (1945-1949), PAT is the organic intellectual who is responsible for instigating journalistic hegemony by making his novel as a medium of communication in order to stir up the ideology and intellectuality of the Javanese marginal class. His goal was to create mental awareness, change the people's common sense and rouse them from the false consciousness created by the bureaucratic elites, the traditional feudal system and Dutch colonizers that wanted to reinforce their hegemony. In the novel titled Sekali Peristiwa di Banten Selatan, for example, PAT endeavours to portray the role of the marginal class through its protagonist, Ranta, who helps to fight Darul Islam/Negara Islam Indonesia (DI/NII) rebels led by Kartosoewiryo (1949) at the end of the Indonesian National Revolution era.

"It's like this, Pak Lurah, we're the ones who should be grateful. Since becoming commandant here, we have succeeded in destroying the gang completely, twice. In fact, its greatest threat. We never dreamed that it could be done." (Pramoedya, 1963: 101) (translated by author)

Based on the perspective of journalistic hegemony, in the citation, PAT degrades the image and role of the local political elite (Pak Lurah) and, instead, praises the capability of the marginal class (Ranta) in this episode, which displays the presence of counter-hegemony. This perspective shows how closely tied is the birth of a literary text to the integration of reality that actually took place and how it is described fictionally in a form and narrative structure of its own by the author. The process of developing it is based on the desire to advance the social group's ideology and intellectuality that they 
represent (marginal class), with the aim of displaying counter-hegemony towards the political society.

The reality depicted in Sekali Peristiwa di Banten Selatan is PAT's effort to recreate the values of life, ideology, desire and worldview as well as spirit of the age of the marginal class that was hegemonized by the political society in Java during the National Revolution. At the same time, the characters, issues and questions during the Indonesian National Revolution focused on the marginal class, such as the characters of Ranta, Rodjali and several more, in PAT's effort to diminish the role of the traditional bureaucratic elites. According to Berger and Luckman (1976: 229), a good literary text is able to rebuild the whole social experience and group interests as represented by its author:

Good literature recreates the sense of life, its weight and texture. It recreates the experiential wholeness of life - of the life of emotions, the life of the mind, the individual life and the social life, the object-laden world. It creates these things all together and interpenetrating, as they do in the live ourselves ... Good literature recreates the immediacy of life.

A good text also refers to the accuracy, honesty and desire of the author to shoulder the responsibility of an organic intellectual in accordance with the interests of the social class he represents. At the same time, the author is responsible for producing his work as a social documentary based on facts and a reflection of events outside the text.

This concept was developed by PAT to show that literary text can be a medium for escaping oppression and class conflict in Javanese society. The narrative element that evolves in a novel or literary text is utilized by PAT to create a certain way of thinking, ideology and intellectuality by placing the novel in a discourse for counter-hegemony by the marginal class. The author is also able to throw around ideas to his readers, such as class freedom, existence of oppression by the political society in Java, gender discrimination and so on. Every element of the narrative in Sekali Peristiwa di Banten Selatan resembles a reality from the journalistic perspective that is depicted by the author via a fictionalized approach. Similar to conventional media, a literary text also involves journalistic activity, editing and publication of a piece of writing or conveying information to the society through the medium of language, creativity and fiction. This activity places the form of literary writing similar to that of news composition since it can be read in order to 
disseminate information and build up the ideology and intellectuality of civil society.

\section{THE PRINCIPLE OF JOURNALISTIC HEGEMONY}

The journalistic hegemony conceptual framework emphasizes that the position of a literary work should be centred around three elements: the author's ideology and intellectuality, the reality of the text's social milieu (text as a social portrayal) and readers as passive receivers of information that is delivered by the author through his work (Azman Ismail, 2014: 224225). The function of the text in this context is as a hypodermic needle that is responsible for "injecting" information into readers in order to create psychological stimulation and awareness, as shown in Figure 1. The effect of reading a literary text is war of awareness, which is mental revolution, a situation that would enable the reader to shed the false consciousness and common sense created by the political society.

Based on Figure 1, the focus of PAT's work is the ideological and intellectual movement of the marginal class with the aim of creating a new hegemony to bring down the hegemony of the political society (Javanese traditional feudal society and Dutch colonizers) and escape the false awareness created by the political elites. The basis of this conceptual framework is the awareness textually, which can lead to the development of an ideological and intellectual marginal class and create a new hegemony that represents the interests of that class. The relationship between the text, author and reader in journalistic hegemony can be explained in that the author is an organic intellectual who becomes the medium to drive forward the ideology

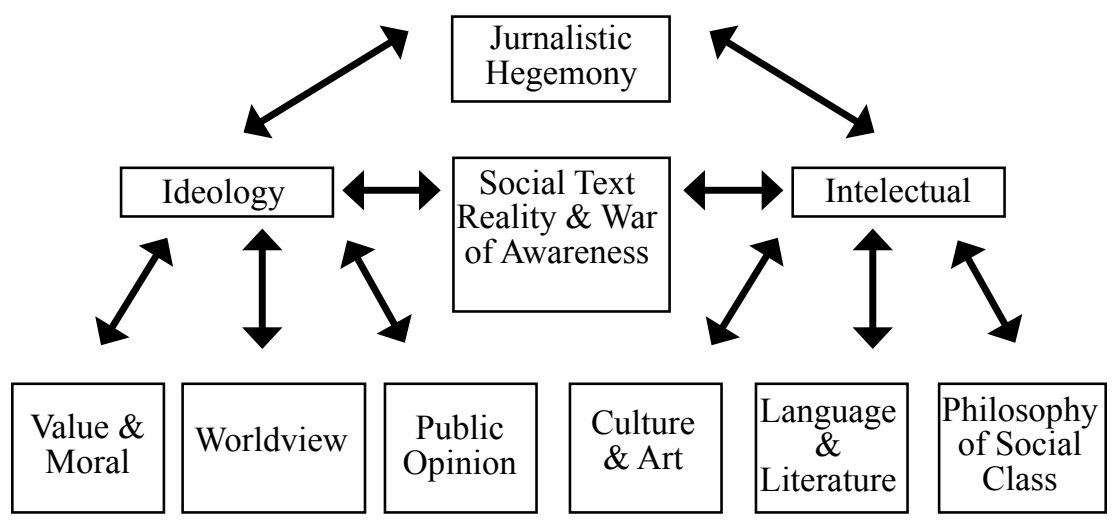

Figure 1 Journalistic Hegemony (Azman Ismail, 2014: 181) 
and intellectuality based on the social text reality, thus giving rise to war of awareness among the readers through the text.

\section{Text's Social Reality}

In the journalistic hegemony conceptual framework, a text is a record and documentation of a society's activities and collective desires. As a social product, a literary text can explain the realities of history, polemics, conflict and all events that take place that are related to social class conflict. The structure of a literary text in the journalistic hegemony perspective has parallels with a society's structure; although both are not directly related, the social system is being fictionalized with the goal of raising class awareness and ideology. In this context, a literary text cannot be fully understood without understanding the social structure on which it is based. Thus, the author will directly function as a medium that links the text and the reader, who will be responsible for transforming the social structure into a text structure with a theme, style of narration and narrative structure that aims to create war of awareness.

Psychologically, the information "injected" by a literary text will influence the reader to become reflective, have a sense of imagination, pay heed to inner feelings as well as possess the mind to think freely about the social structure being depicted (Azman, 2014: 16-18; Digman, 1990: 41). The reading of the text will also inculcate agreeableness, or a feeling of sympathy towards other individuals, which will deter feelings of antagonism among readers. Agreeableness towards any information conveyed by an author in a literary text will also create a collective collaboration that will spark common interest among members of the social group. The result from this interaction will inspire a feeling of togetherness and also responsibility because they have the same social needs.

\section{The Ideology and Intellectuality of the Author}

Every author in the journalistic hegemony framework is an intellectual with the potential to develop an ideology and the intellectuality of the social class he represents. The author's main function is to foster class awareness so that the reader can be free of false consciousness and be fully responsible in building political awareness through moral leadership and social awareness in the marginal class in a comprehensive manner (Azman \& A. Halim, 2015; Gramsci, 1971: 16). In order to ensure that such awareness is brought about, authors use their texts to develop cognitive psychology, which is a process to change a society's way of thinking and free them from false consciousness 
perpetuated by the powerful elites that are dominant or hegemonic. A text becomes the vehicle for "injecting" information and cognitive psychology elements in order to form a historically organic ideology. This term refers to the formation of a new ideology for the marginal class so they can be free from the way of thinking and moral leadership exercised by the powerful elites. This term also refers to the building of a historical bloc, that is, an ideology and intellectuality that is free from the cocoon of the political society.

In accordance with the function of a text as a medium for journalistic hegemony, novels and other literary works focus on delivering empowering information, identity building, awareness and reinforcement of the ideology of the marginal class (reader), who is the "enemy" of the political society. Language in the context of the journalistic hegemony conceptual framework becomes very important in understanding the workings of the author's mind in the text, other than to function comprehensively as the idea, discourse and description of the ambitions of the social class he represents. The philosophy behind the author's intellectuality refers to the common sense and worldview of the marginal class created by the author in the text that is linked to the phenomena and critical thinking being elaborated on a wide scale.

\section{War of Awareness}

The most important element in the journalistic hegemony conceptual framework is war of awareness, which refers to an ideological and intellectual movement by an author to raise mental awareness and change the worldview of the marginal class in terms of perspective, understanding, way of thinking, worldview and common sense. If war of position, as put forth by Gramsci in the theory of hegemony, is a form of ideological movement by the marginal class in a subjective manner, then war of awareness is of an objective nature directed in the context of a literary work's function. When looking at it in detail, Gramsci's war of position places ideology and intellectuality in a general scope, that is, it encompasses all aspects of life and aspirations of the marginal class, whether in the arts, politics and social institutions, in order to achieve the objective of a new hegemony (Azman \& A. Halim, 2015; Nezar Patria \& Andi Arief, 1999: 18-21; Heru Kurniawan, 2007). A literary text in this context arouses the elements of remorse and new cognitive psychology in order to germinate awareness and a desire to change and free oneself from the moral leadership of the political society.

At this stage, a literary text functions as a hypodermic needle, bringing forth the author's way of thinking, ideology and aspirations to change the 
worldview as well as the common sense of the readers through the use of fictitious characters. War of awareness is focused on the structural link between the mental awareness of the author as an organic intellectual that is transformed through the literary work and the structure of the thinking of the readers who make up the group of information receivers. The final role of the literary text in the journalistic hegemony conceptual framework is the mental change in the readers, which can be understood textually. This conceptual framework emphasizes on the readers' mental change, which can be understood through their acceptance and evaluation of the literary text.

The mental awareness built up by PAT in Larasati, Sekali Peristiwa di Banten Selatan, Keluarga Gerilya and Di Tepi Kali Bekasi is transformed into an ideological and intellectual movement, and consequently becomes a form of creative media that functions as a vehicle in the formation of marginal hegemony. In all four novels that deal with the theme of revolutionary war, he is able to bring forth the ideology and intellectuality of the marginal Javanese through his protagonists: Larasati (Larasati); Ranta, Rodjali and Ireng (Sekali Peristiwa di Banten Selatan); Canimin, Amilah, Salamah, Sa'aman and Kartiman (Keluarga Gerilya) and; Farid (Di Tepi Kali Bekasi). Through these characters, PAT builds up a historical bloc and solidarity bloc of the marginal class, apart from bringing this social class out of the domination of the colonizers and native bureaucratic elites. From this connection, the novel directly becomes an instrument of creative media that the author uses to report on every phenomenon, issue and conflict between the marginal and political societies. In this situation, the characters become the symbols and codes that represent the perspective, worldview, common sense and aspiration of the author, who is the link with the social system he represents (Fiske, 2011:1-2).

\section{IDEOLOGY AND INTELLECTUALITY IN PAT'S NOVELS}

Gramsci defines ideology as "a scientific hypothesis which has a dynamic educational character and is verified and criticized by the actual development of history" (Forgacs \& Nowell, 1985: 124). According to Gramsci, the function of ideology and intellectuality is to act as a medium for arranging and building awareness on the position and existence of a social class in order to create a historical bloc and a solidarity bloc. He describes ideology as a very deep feeling that enables an individual or group to understand various issues based on the collective interests of a social class (Gramsci, 1971: 63). From the perspective of journalistic hegemony, ideology is a value that a social class - be it the marginal class or the powerful elites - wants to achieve 
through creative or non-creative texts. The objective is to become a medium of commonality of ideas, emotions, values and morals, sociocultural matters and the arts, which can lead to the achievement of collective aspirations. According to this conceptual framework, in the novel titled Larasati, for example, PAT presents the title character as a representative of the marginal class to counter the status quo in order to create a new hegemony against the native bureaucratic elites:

The Revolution is not finished at all, though many officials and leaders have raised the white flag! He smiled. I am defeated now but the Revolution is not! I lost but tomorrow, maybe the day after, maybe next month or next year, I will win it! The heart is pounding. He is affected. His eyes glaze. How noble that the young man still upholds the struggle! (Pramoedya, 2003:160) (translated by author)

Based on these remarks, PAT portrays Larasati as a marginal class character who plays an important role in the Indonesian National Revolution, at a time when there were still a few native bureaucratic elites in Java who preferred to support the Dutch in order to maintain their elite lifestyle. PAT, on the other hand, attempts to "erase" the existence of the political society by providing an image of a strong ideology and intellectuality through Larasati's character in the revolution. These remarks are aimed at forging war of awareness by the marginal class, which would lead to counter-hegemony against the political society (Azman, 2014: 88-90).

The question of values and morals is also one of the main ideological and intellectual elements of the marginal class that PAT highlights by making his novel a medium, with the assumption that each subject and issue expressed by him is aimed at influencing the reader's awareness (Azman, 2014: 182-184; Evinaro Ardianto et al., 2004: 19). Values are the attitudes and feelings towards a subject that involves good-bad, should-should not, honourable-deplorable, significant-insignificant, important-trivial and various other elements that form two opposing sides.

Unlike the character of Larasati, in the novel titled Sekali Peristiwa di Banten Selatan, PAT "injects" mental awareness in his readers by creating marginal class characters that are poor, foolish and tied to the system built by the native bureaucratic elites as a symbol of war of awareness. At the same time, he shows the negative way of thinking of the bureaucratic elites as a way of rousing war of awareness among the marginal class, such as the 
dialogue by the wife of Ranta (a character from the Javanese marginal class) with the wife of Juragan Musa (a native bureaucratic elite):

"Mam, your husband does not want to hire me. So he accused me and chased me away. If I'm not mistaken, Juragan Musa has accused many people of stealing his things right? But what is the point, people like me, rubber seed thief" (Pramoedya, 1963: 82) (translated by author)

The character of Ranta is originally under Juragan Musa's hegemony, which has close ties with the Darul Islam rebels who caused chaos and extortion on the society in Banten, West Java, which is the backdrop of this novel during the era of the National Revolution. Here, PAT directly functions as a reporter and journalist by delivering information on the negative values and morals of the political society through the character of Juragan Musa, who finally teams up with Ranta and the villagers to fight the Darul Islam movement.

The Darul Islam movement was an effort to create an Islamic Indonesia, inclusive of several sections in West Java, Indonesia, and led by Maridjan Kartosoewiryo since August 7, 1942 (Lucas, 1989: 196-197). Among its main objectives were to make Islam the basis of Indonesian administration after the Proclamation of Independence on August 17, 1945. In terms of morals and values, PAT expresses a marginal class ideology that the collective war of awareness will succeed in destroying the political society's hegemony, as seen in the conflict between Juragan Musa and Ranta. The rationale behind the war of awareness in Sekali Peristiwa di Banten Selatan is to move towards the formation of a new hegemony led by the marginal class. As stated by PAT: "I hear it everywhere: The truth will finally win. That is true. Very true. But when? The truth will not fall from the sky, it must be fought for to make it true" (Pramoedya, 1963:77) (tranlated by author).

PAT, as an organic intellectual, reinforces the values and morals of the marginal class that he represents in order to acquire the values or acknowledgment of status and social recognition to achieve hegemony of the marginal class that he represents. For him, the characters of Ranta, Rodjali and several others from the marginal class are the medium to spur war of awareness against the powerful elites in Banten after the Proclamation of Independence. In this context, the literary text stirs up feelings of remorse and cognitive psychology, which will increase awareness and desire to change and escape the moral leadership created by the political society over the characters in the marginal class. 
The marginal class' ideology and intellectuality that is developed by the author become the image of awareness and opposition towards all forms of moral leadership created by the powerful elites (Azman, 2014: 192-193). Through Keluarga Gerilya, PAT deals with the issue of morals and values as a way of "reporting" the various injustices of the colonial system and the native bureaucratic elites, which leads to the oppression of the marginal class represented by Amilah, Sa'aman, Sanimin, Salamah, Patimah and others.

An informatic image is built up by PAT in Keluarga Gerilya to show the side-lining of the marginal class, which leads to an element in war of awareness that finally reinforces the common sense of the civil social class he represents. The informatic image is symbolized through Amilah's family. The term "informatic image" is used by Gramsci to refer to the way a noncritical and unaware person views the world (Simon, 1999: 20). Gramsci uses this term to describe a civil society that is not critical and unaware in their perception of the world and in their way of thinking, while still having the same outlook as the dominant class (political society).

The informatic image of values and morals is portrayed by PAT in Kelurga Gerilya through the patricide committed by Kartiman, who is honest about carrying out his duty as a corporal in the Indonesian guerrilla army. Kartiman's father was a soldier in NICA (Nederlands Indie Civil Administration), the Dutch army that was responsible for crushing the struggle of the Indonesian people during the National Revolution, which, at the same time, challenged the country's declaration of independence. Kartiman is very reluctant to carry out the killing of his father as it has to do with morals and values. This can be proven in the dialogue below:

"I'm saying, don't be swayed by your nonsensical feelings," said Corporal Canimin. "You're a good and disciplined soldier. If your own father allies himself with the enemy and the enemy wants to kill us, who should finish off your father if not you? You should think like that. Maman! Think, if your father falls into another army's hands, it will be worse for him. Think, he may even be killed with a bamboo spear." (Pramoedya, 1955: 29) (translated by author)

From the journalistic hegemony perspective, a new hegemony can only be achieved when there is mental awareness, a change in worldview, a change in values and morals as well as a change in the way of thinking of the social classes that are hegemonized. In order to form a new hegemony, the awareness brought about by a literary text must represent the common sense, 
worldview and collective behavioural patterns of the marginal class, while moral values must represent the collective interests of the marginal class. This means that in the marginal class, there should be strength in ideology, intellectuality, mental awareness, sociopolitics and so on in order to form a solidarity bloc that can represent all the aspirations of the marginal class, such as those presented by PAT in his four novels.

Apart from the issue of war and conflict of interest, the socioeconomic and sociocultural aspects are also major issues in the four novels by PAT. These issues are brought up to show how the political society use them to create false awareness. False awareness is a situation whereby the dominant class gains the trust and agreement of the marginal class to form a hegemony through a worldview endorsed by the marginal class and the subaltern group. Journalistic hegemony also places socioeconomic and sociocultural issues as the major foundation in the formation of the ideology of marginal and subaltern groups. However, in order to create a new hegemony, organic intellectuals must play their part to bring about awareness and change the society and their way of thinking and worldview, apart from behavioural and moral values as well as socioeconomic issues (Bocock, 1986: 73-74). In Larasati, for example, a new hegemonic awareness of the marginal class is shown through a narrow-minded statement made by one of the antagonists, Mardjohan, when referring to the sociocultural and socioeconomic situation: "Asians like us, Ara, are ridden with gratitude. I owe a lot to the colonel. He is my saviour, from death, from hunger. In the past. Don't you don't owe anyone, Ara?" (Pramoedya, 2003: 51) (tranlated by author).

As an organic intellectual, PAT symbolized the marginal class' suffering and side-lining through the conflict between Larasati and Mardjohan as a discourse on war of awareness. He used Larasati as a medium to "inject" his thoughts on sociocultural and socioeconomic matters to the readers in the hope that it will evoke an image of awareness. Similarly, in Keluarga Gerilya, PAT expressed the suffering and the marginalization of Amilah's family as a statement on war of awareness: "A lamp that flares restlessly - a lamp like other lamps, a lamp that symbolizes poverty of the human family. It burns red-yellow. And all the shadows in the house shake when the flame is swayed by the wind" (Pramoedya, 1955: 4) (tranlated by author).

“...You're all still young, and youth is valuable, my brothers! Now you don't feel it. But later, if you waste your youth now to chase meaningless things, and when you are old and in a mess, then you'll know the value 
of your youth. Because of that, use it wisely. Do it ..." (Pramoedya, 1955: 187) (translated by author)

An element of the awareness movement is also evolved through the character named Farid in Di Tepi Kali Bekasi, which guides the revolutionary movement to oppose the Dutch colonizers who were supported by the native political elites in order to regain power. Farid, who leads the Indonesian youth movement, realizes that the real war for the Indonesian nation is to be free of the colonial mental shackles and slavery after 350 years under the Dutch regime:

...the ways of fighting without preparing the education of the army, without strategy, without the necessary tools, after being free of the grip of hunger is the time for mental revolution - from being colonized and enslaved to a free soul... (Pramoedya, 1951: 247) (translated by author)

The character of Farid in this context is portrayed as a representation of the worldview and common sense of the marginal class in Indonesia, similar to the characters of Larasati (Larasati), Sanimin, Sa'man, Patimah and Amilah (Keluarga Gerilya) and Ranta and Rodjali (Sekali Peristiwa di Banten Selatan). Through these characters, PAT has built the image of marginal class ideology and intellectuality through their conflict with the native political elites. For example, in Larasati, he demonstrates a debate between Larasati, who represents the marginal class, and Mardjohan, who represents the native elites and is in awe of the Dutch, citing gratitude as an excuse. In the conflict between the characters in all four novels, PAT, as an organic intellectual, has pushed forward war of awareness in the effort to create counter-hegemony to the political society. Conceptually, this is similar to the information gained by a reader of conventional media (newspaper and magazine) by a reporter, journalist or columnist who inspires knowledge, awareness and desire for change (Azman, 2014: 193-194)

\section{CONCLUSION}

PAT uses the "creative reporting" approach to develop hegemonized characters, such as Larasati, Farid, Ranta, Rodjali, Sanimin, Sa'aman, Amilah, Patimah and others, in the four novels revolving around the Indonesian National Revolution. The objective is to build an image of counter-hegemony and war of awareness by the marginal class and subaltern group in Dutch Indies (Indonesia) against the native bureaucratic elites and Dutch colonizers. The 
concept of war of awareness brought by PAT in these four novels function as a superstructure, or a form of internal consciousness, whereas the novel itself is the tool (structure) that has the function of consciousness. The text (novel) is the structure that functions similar to a hypodermic needle, that is, to "inject" information in the same way as conventional mass media in order to activate the superstructure. In this case, it is to bring about awareness in the marginal class in order for them to form counter-hegemony.

War of awareness, which is the main principle in the journalistic hegemony conceptual framework, can also be seen as a method of understanding literary works, including novels, not only as creative pieces of work but also as a reading of society's social structure. A text not only focuses on the structure (physical nature) but also on the superstructure (metaphysical nature), which functions as a collective statement of a society's worldview and common sense of a social class represented by the author. In this context, the four novels with the revolutionary war theme provide a dimension for understanding the position of a literary text and how it has the same functional structure as conventional media.

\section{REFERENCES}

Astrid S. Susanto. (1987). Komunikasi: teori dan praktis 2. Kuala Lumpur: Dewan Bahasa dan Pustaka.

Azhar Hj. Wahid. (2011). Hegemoni intelektual kolonialisme dalam novel Melayu. Jurnal Melayu. 6 (2011), 169-185.

Azman Ismail. (2014). Novel-novel Pramoedya Ananta Toer dalam analisis hegemoni jurnalistik (Unpublished Doctoral dissertation). Univerisiti Pendidikan Sultan Idris (UPSI).

Azman Ismail \& A. Halim Ali. (2014). Hegemoni jurnalistik dalam kajian tetralogi Bumi Manusia karya Pramoedya Ananta Toer. Jurnal Rumpun. 2 (2014), 1-40. Azman Ismail \& A. Halim Ali. (2015). Hegemoni jurnalistik sebagai kerangka konseptual dalam kajian kesusasteraan. The International Journal of Arts, Culture \& Heritage (iJACH), 2, 22-47.

Berger, Peter L. \& Luckman, Thomas. (1976). The social construction of reality: A treatise in the sociology of knowledge. Peguin Books.

Bierstedt, Robert. (1950). An analysis of social power. American Sociological Review, 15(6), 730-738.

Bocock, Robert. (1986). Hegemony. Tavistock.

Clark, Martin. (1977). Antonio Gramsci and the revolution that failed. Yale University Press.

Digman, J. (1990). Personally structure: emergence of the five-factor model. Annual Review of Psychology, 41, 417-440. 
Eagleton, Terry. (1996). Literary theory: An introduction (second edition). The University of Minnesota Press.

Elvinaro Ardianto et al. (2007). Komunikasi massa: satu pengantar. Simbiosa Rekatama Media.

Femia, Joseph (1981). Gramsci spolitical thought: Hegemony, conciousness and the revolutionary process. Oxford University Press.

Forgacs, D. \& Nowell G, (Eds.). (1985). Antonio Gramsci, selection from cultural writing, (William Boelhower, Trans.). Lawrence \& Wishart.

Forgacs, D. (1989). Gramsci and Marxism in Britain. New Left Review, 176 (1), 70-88.

Fiske, John. (1989). Understanding popular culture. Unwin Hyman.

Gramsci, Antonio. (1971). Selections form the Prison Notebook, (Quintin Hoare \& Goffrey Nowell Smith, Trans.). Lawrence and Wishart.

Heru Kurniawan. (2007). Relasi formatif Gramsci dalam novel Perburuan karya Pramoedya Ananta Toer. Jurnal Studi Islam dan Budaya, 5(1), 157-175.

Ives, Peter. (2004). Gramsci's politics of language: Engaging the Bakhtin circle and the Frankfurt School. University of Toronto Press.

Joll, James. (1977). Gramsci. William Collins Sons \& Co. Ltd.

Langland, Elizabeth. (1984). Society in the novel. University of South Carolina Press.

Laughey, Dan. (2007). Key themes in media theory. Open University Press.

Littlejohn, Stephen W. (1999). Theories of human communication. (6th Edition). Wadsworth Publishing Company.

Lucas, Anton E. (1989). The bamboo spear pierces the payung: the revolution against the bureacratic elite in North Central Jawa 1945. Pustaka Utama Grafiti.

Lukacs, Georg. (1971). History and class consciousness: Studies in Marxist dialectics. Merlin.

MacDougall, Curtis D. (1972). Interpretative reporting. Sixth Edition. Macmillan.

Misran Rokimin (2006). Isu pendidikan dan pembangunan insan menerusi novel. Penerbit UKM.

Nezar Patria \& Andi Arief. (1999). Antonio Gramsci, negara dan hegemoni. Pustaka Pelajar.

Pramoedya Ananta Toer. (1951). Ditepi kali Bekasi. Balai Pustaka.

Pramoedya Ananta Toer. (1955). Keluarga gerilya. Penerbit Pembangunan Djakarta. Pramoedya Ananta Toer. (1963). Sekali peristiwa di Banten Selatan. N.V Nusantara. Pramoedya Ananta Toer. (2003). Larasati. Lentera Dipantara.

Riley, Dylan J. (2011). Hegemony, democracy and passive revolution in Gramsci's Prison Notebook. Californian Italian Studies, 2(2), 176-201.

Sassoon, Anne Showstack. (2006). A Gramsci dictionary. In Approaches to Gramsci. Anne Showstack Sassoon (Ed.). Writers and Readers Publishing Comparative Society Ltd.

Simon, Roger. (2001). Gramsci's political thought: an introduction. Lawrence and Wishart. 